\title{
Main Effects and Interaction Effects of Bank Ownership Types and Bank Core Capital Category to The Bank NPL Performance
}

\author{
Fongnawati Budhijono \\ Universitas Prasetiya Mulya, DKI Jakarta 12430, Indonesia
}

\begin{abstract}
A B S T R A C T
Credit management capability is seen as a crucial aspect for banks sustainability. The variable that is directly related to bank credit risk is a non-performing loan (NPL) which is commonly used to assess the asset quality of a bank. The purpose of this research is to analyze main effects and interaction effects of bank ownership types and bank core capital category (BUKU) to the bank NPL performance. The study was conducted using secondary data obtained from bank quarterly reports from the Financial Services Authority (OJK) through the website ojk.go.id, bank financial reports, and infobank magazine. Bank's performance in the classification of bank ownership types and bank core capital category were evaluated with respect to bank's NPL which in this case is used as indicator of the bank's performance. Tests were performed using TWO WAY ANOVA and Post Hoc Test. The findings of this study found that the main effect type of bank ownership had a significant effect on the performance of NPL management, the main effect of banks' BUKU had no significant effect on the performance of NPL management and the interaction effect of bank type and banks' BUKU had a significant effect on the performance of NPL management.
\end{abstract}

ARTICLE INFO

Article History:

Received : 08-10-2020

Revised : 22-01-2021

Accepted : 05-02-2021

Published : 15-02-2021

Keywords:

Bank

Core Capital

Non-performing Loan

Ownership Type
*Corresponding Author E-mail:

fongnawati.budhijono@lecturer.pmsbe.ac.id

Copyright (C) 2021 Authors. This is an open access article distributed under the Creative Commons Attribution License (CC-BY-SA 4.0) which permits use, distribution and reproduction in any medium, provided the original work is properly cited \& ShareAlike terms followed.

\section{INTRODUCTION}

As a developing country, Indonesia needs banks as facilitators in channeling funds. The role of banks as financial intermediaries is very important so that credit distribution grows stably (Gurley, Shaw \& Enthoven, 1960; Diamond D, 1984)). Banks are crucial institutions for turning the wheels of the economy (Global Association of Risk Professionals, 2005; Global Association of Risk Professionals, 2006).

Indonesian credit distribution grew by an average of $7.09 \%$ for Commercial Banks with the latest 
record showing that credit was disbursed at IDR 7,667.803 billion (Otoritas Jasa Keuangan, 2019c). The provision of credit by banks has also experienced an even development in terms of the proportion of credit disbursed. As much $46.48 \%$ of the total credit was used for working capital, $27.64 \%$ for consumption, and the rest for investment (Otoritas Jasa Keuangan, 2019c). The proportion of credit used has also experienced mixed growth over the last 5 years, but it has continued to score growth of above $10 \%$ and shows the rise of aggregate credit growth since 2018. Credit growth of $10 \%$ on average in the last 5 years is a glimpse of the potential of Indonesian people who are not all familiar with bank institutional instruments (Otoritas Jasa Keuangan, 2019e).

With the strategic role of the bank, in order to maintain its survival banks must have a good performance (SE BI No. 13/24/DPNP). The survival of the bank has received serious attention from all stakeholders, especially because most of the fund assets in the bank come from third party funds or funds originating from the deposits of their customers. Bank failure could affect depositors, and cause spillovers both domestic and international markets (Sugiarto, 2016; Sugiarto, Nursiana Adinoto, Budhijono Fongnawati, 2018).

As an industry that inherently carries risks that cannot be eliminated as a whole, banks operating in Indonesia are closely monitored by Bank Indonesia (BI) and the Indonesian Financial Services Authority (OJK), which are the agencies appointed by the Indonesian government to maintain the stability of the banking industry. In relation to its function as an intermediary institution, the survival of a bank is highly dependent on its risk management performance (SE BI No.13/23/DPNP/2011). Based on Bank Indonesia Circular 6/23 / DPNP of Commercial Bank Soundness Rating System and attachments, a bank's Risk Profile can be further classified into: credit risk, market risk, liquidity risk, operational risk, legal risk, strategic risk, compliance risk, and reputation risk (SE BI No.13/23/DPNP/2011; Global Association of Risk
Professionals, 2005; Global Association of Risk Professionals, 2006).However, the quantitative risk profile only covers credit risk, liquidity risk and market risk, so the risk profile assessment section contains aspects of asset quality, liquidity aspects, and aspects of economic risk factors. Credit risk is undeniably getting serious attention because weak credit management will result in the emergence of liquidity risk and market risk. Poor credit management will impact on the low ability of banks to generate profits. Thus, credit management capability is seen as a crucial aspect for bank sustainability (Diamond, D., \& Rajan, R. (2001).

The variable that is directly related to credit risk is a non-performing loan (NPL) which is commonly used to assess the asset quality of a bank (Sugiarto, 2016; Sugiarto, 2017a; Sugiarto, 2018). NPL can be used as a proxy for asset quality to be a variable that affects profitability because it shows the risk of financing, where the high value of the NPL indicates that there is a lot of bad financing that affects the profitability of the bank (Sugiarto, 2018; Sugiarto \& Karnadi Suryadi, 2018; Kohlscheen, Et.al, 2018). A bank will be indicated as a bank with a lot of non-performing loans if it has a high NPL ratio. This needs to be a concern because of the potential for default by credit customers. Asset quality measurement can assess the collectability level of the bank, current, doubtful, or loss. The three levels of collectability are used to measure and prepare the lower limit of reserves that need to be prepared by the bank to be responsible for losses from credit risk.

The Indonesian banking industry records five types of bank ownership, namely foreign bank, mixed bank, regional development banks (BPD Bank), state-owned commercial banks (BUMN Bank) and private bank (Undang-undang Republik Indonesia Nomor 10 Tahun 1998). The ownership structure of a bank can simply be done by looking at the composition of the parties who have rights over the ownership of the bank. The presence of foreign banks can increase competitive behavior based on the capabilities of foreign banks in carrying out their operating costs which are much 
more efficient than local banks (Crystal, J.S., Dages G., Goldberg, L.S., 2001; Claessens, S., Demirgüc, Kunt, A., \& Huiinga, H., 2001; Manlagnit, Maria Chelo V., 2011; Lardy, N. R., 2001). With much lower operating costs, foreign banks have been shown to provide lower spreads compared to local banks. Pressure caused by low spreads and operating costs caused local banks to be cornered to seek new sources of income that did not come from lending activities. Capital loans in foreign currencies made through foreign banks give the country a big advantage (Crystal, Dages, \& Goldberg, 2001). This indirectly allows countries to obtain foreign exchange capital from international markets (Claessens, S., Demirgüc, Kunt, A., \& Huiinga, H., 2001). The presence of foreign banks can add product variety to the financial system and banking transactions with increased competition. Banks that are classified as foreign bank, mixed bank, regional development banks (BPD Bank), state-owned commercial banks (BUMN Bank) and private bank also have their respective characteristics with advantages and disadvantages as well as operating complexities that differ from one another (PBI No. 14/26/PBI/ 2012). The difference in the types of bank ownership will allegedly affect their performance in managing NPL (PBI No. 5/8/PBI/2003; PBI No.13/1/PBI/2011).

In addition to the classification of banks based on ownership types, there is also a classification of Commercial Banks based on Business Activities what is known as BUKU (Bank Umum Kegiatan Usaha, Commercial Bank Business Activities). There are 4 types of BUKU which are known by Indonesian Banking (POJK No. 6/POJK.03/2016; Boby, 2019). It is in its own interest to discuss because each level of BUKU has limitations on banking activities that can be carried out. This has an impact on the performance of banks operating in Indonesia as well as their competitive position (Sugiarto, 2017a; Sugiarto, 2017b). The public perception declared that major banks is more difficult to bankrupt than smaller banks, implicitly imply that big banks should have better performance than smaller banks, including in their ability to manage non-performing loans
(Sugiarto. 2016).

Variations in types of bank ownership and variations in the classification of Commercial Banks based on Business Activities (BUKU) may interact to bring about specific performance including in the management of banks' NPL. Analysis of the interaction of the variable types of bank ownership and the variable classification of commercial banks based on business activities will be novelty in this research.

In the Indonesian laws and regulations governing banking, namely article 5 of Law No. 10 of 1998 (Undang-undang Republik Indonesia Nomor 10 Tahun 1998), there are two types of banks, namely Commercial Banks and Rural Banks (BPR). This research focuses on commercial banks and does not discuss BPR. Related to the five types of bank ownership, in this study the researcher used four categories in which banks with foreign and mixed ownership were classified into one category.

The purpose of this research is to analyze the effect of bank classification based on types of bank ownership, the effect of bank classification based on core capital category (BUKU), and the effect of the interaction of types of bank ownership and the category of core capital (BUKU) to the bank NPL performance. This research problem formulation are as follows:

1. Does the classification of the bank based on types of bank ownership affect the performance of the bank's NPL?

2. Does the classification of the bank based on the category of core capital (BUKU) affect the banks NPL performance?

3. Does the interaction of types of bank ownership and the category of core capital (BUKU) affect the bank NPL performance?

\section{LITERATURE REVIEW}

\section{Financial Intermediary}

The main function of a bank is as a financial intermediary (Gurley, Shaw \& Enthoven, 1960). As a financial intermediary, a bank can act as a licensed agent to deposit funds in order to achieve better economies of scale (Leland \& 
Pyle, 1977; Diamond, 1984). Gurley, Shaw \& Enthoven (1960) say that this theory was born due to high transaction costs, lack of information when needed, and regulatory methods. The theory deviation from the perfect market as well as the difference in objectives and information between the agent (the person who carries out) and the principal (the person who owns it) can explain transactions that are more expensive than what is triggered in the perfect market theory so that the formation of this intermediary financial theory helps at least to explain high transaction costs. The existence of this Financial Intermediary theory produces a solution by establishing an intermediary institution that can provide relevant information when needed with clear regulations and relatively cheaper costs.

In resolving information imbalances, banks can mediate between depositors and borrowers to ensure that the principal deposit is safe and can make a profit, while the borrower can receive relatively cheap and fast financing against liquidity risk (Leland H., \& D. Pyle, 1977); Diamond D. 1984; Otoritas Jasa Keuangan, 2019a). This can reduce liquidity risk based on the selection process for borrowers who have the ability and willingness to repay.

Based on the high transaction cost approach, Fama (1980) argues that in the description of high transaction costs, it is not only transfer costs for other countries' currencies, but there are research and development efforts in changing the nature of assets into opportunities for asset diversification. The approach questions the existence of a method to regulate the circulation of money in economic storage and financing that affects the health of the bank, its ability to extend credit and make provisions (Diamond \& Rajan, 2001).

\section{Non Performing Loan}

A healthy bank is not only measured by profitability indicators because the bank itself is a medium facility for people who want to borrow and save so that they have the obligation to handle third party funds responsibly. For the same reason, the banking industry is bound by many regulations. In the banking world, there are several ratios that are commonly used in the banking world, including CAR, NPL, NIM, COR, and LDR (Hutagalung, E.N. Djumahir. \& Ratnawati, K.,2013) which comes from published financial reports so that management can make judgments related to decision making ( Jonathan Batten \& Xuan Vinh Vo.,2019; Kohlscheen, et.al. , 2018).

Non Performing Loan (NPL) is a bank indicator that is useful for assessing the asset quality of a bank. Non Performing Loans (NPL) is the ratio of total non-performing loans to total loans extended by banks. A bank will be indicated as a bank with a lot of non-performing loans if it has a high NPL ratio. This needs to be a concern because of the potential for default by credit customers. Asset quality measurement can assess the collectability level of the bank, current, doubtful, or loss. The three levels of collectability are used to measure and prepare a lower limit of reserves that the bank needs to prepare to be responsible for losses from credit risk. NPL is a credit channeled that is said to be problematic if the repayment is late compared to the planned schedule, or not even at all. The bad impact of this NPL is supported by the finding that large amounts of non-performing loans can have an unfavorable impact both for the lending bank, the banking industry in general, as well as on the economic life or the country's monetary condition (Prasetyo, W, 2015). NPL is one of the key indicators to assess whether a bank is performing well or not. High NPL on the bank indicates a problem in the bank that if they do not immediately get a solution would jeopardize the bank's condition. With the higher NPL ratio of banks, the level of bank liquidity against third party funds will be lower. Regardless of any factors that cause high NPLs, the bank's inability to manage the NPL indicates the ability of bank management is not promising (Sugiarto, 2016; Sugiarto. 2018; Sugiarto \& Karnadi Suryadi. 2018).

\section{Bank Ownership in Indonesia}

The Indonesian banking industry classifies the 
existence of five types of ownership, that is: foreign banks, mixed banks, regional development banks (BPD Bank), state-owned commercial banks (BUMN Bank) and private banks. Determination of ownership of a bank is recorded in Act number 7 of 1992 as amended by Act number 10 of 1998 (Undang-undang Republik Indonesia Nomor 10 Tahun 1998). To determine the ownership structure of a bank, it can simply be done by looking at the composition of the parties who have rights over ownership of the bank. Based on the ownership of the banking institution, banks can also be divided according to which party has the largest proportion of the bank. Banks that are classified as foreign bank, mixed banks, regional development banks (BPD Bank), state-owned commercial banks (BUMN Bank) and private bank, also have their respective characteristics with advantages and disadvantages as well as operating complexities that differ from one another. Unite and Sullivan (2003) stated that the presence of foreign banks was able to increase banking competitive behavior. The difference in the types of bank ownership will allegedly affect their performance in managing NPL (Anbar, A., \& Alper, D., 2011; Yüksel, S.; Mukhtarov, S.; Mammadov, E.; Özsarı, M,2018). Foreign competition compels domestic banks to be more efficient to focus operations due to increased risk, thereby affecting the NPL performance of banks (Unite and Sullivan, 2003). Foreign bank is proven to be superior compare to domestic banks in terms of profitability and cost-efficiency. The presence of foreign banks increases competition and risk management performance (Susanto, Anindya Pradipta \& Rokhim Rofikoh, 2011).

\section{Bank's core capital}

One of the indicators related to bank size is the bank's core capital. In banking operational activities in Indonesia, the bank's core capital (Tier 1 capital) is the basis of the BUKU banking (Bank Umum Kegiatan Usaha, Commercial Bank Business Activities). BUKU banks are divided into 4 major groups, where the differentiating factor is the core capital of each bank (PBI No.14/26/ PBI/2012; PBI No. 14/18/PBI/2012; POJK No. 6/
POJK.03/2016), This grouping applies to all types of banks, both for Islamic and conventional banks (Otoritas Jasa Keuangan, 2019b; Otoritas Jasa Keuangan, 2019d).

Indonesia recognizes four categories of BUKU Banks, namely BUKU 1, BUKU 2, BUKU 3, and buku 4. A bank categorized as a BUKU 1 is a bank with a core capital of up to IDR 1 trillion, or in other words a bank categorized as a BUKU 1 is a bank with a minimum core capital. A bank that is categorized as a BUKU 2 is a bank that has a core capital of between IDR 1 trillion and IDR 5 trillion. Bank BUKU 3 has a core capital of between IDR 5 trillion and IDR 30 trillion. Bank BUKU 4 has a core capital of over IDR 30 trillion (SE BI No. 14/37/DPNP/2012). With higher amount of core capital or BUKU classification, a bank will get the right to carry out more business activities, thus creating new opportunities for banks to generate profitability (PBI No. 14/26/PBI/2012). Damayanti, P., \& Savitri, D. A. M. (2018) found that the bank size and capital adequacy ratio (CAR) has positive effect on the bank profitability performance, the higher the capital adequacy ratio (CAR), the better the bank's profitability performance. However, the capital adequacy under their study has not been classified into banks BUKU. Growing perception in the community that the large banks go bankrupt more difficult than smaller banks, implicitly imply the view that big banks should have better performance than smaller banks, included in the NPL management capacity (Sugiarto. 2016). However Sugiarto (2016) found not enough evidence to conclude that bigger banks with higher core capital classification have better performance than smaller banks with lower core capital classification after the bank's core capital has been classified in banks BUKU.

\section{Hypothesis Development}

In this study, three hypotheses were developed to be tested.

1. The classification of the bank based on types of bank ownership affect the performance of the bank's NPL

2. The classification of the bank based on the 
category of core capital (BUKU) affect the banks' NPL performance

3. The interaction of types of bank ownership and the category of core capital (BUKU) affect the banks' NPL performance

\section{RESEARCH METHOD}

The study was conducted using secondary data obtained from bank quarterly reports from the Financial Services Authority (OJK) through the website ojk.go.id, bank financial reports, and infobank magazine. As the research variable is NPL which in this case is used as indicators of the bank's performance. Bank's performance in the classification of bank ownership types and bank core capital category were evaluated with respect to bank's NPL. Tests were performed using Two Way ANOVA and Post Hoc Test.The bank prerequisites being considered are as follows:

1. Registered in OJK

2. Attach a complete quarterly financial report to the OJK for the period 2014-2019

3. Grouping of banks has done according to the rules of $\mathrm{BI}$ on commercial banks business activities (BUKU)

In this research, there are four classifications related bank ownership types, namely:

- Foreign bank and mixed banks code 1

- Regional development banks (BPD Bank) code 2

- $\quad$ State-owned commercial banks (BUMN Bank) code 3

- $\quad$ Private banks code 4

In this research, there are four classifications related bank core capital (BUKU), namely:

- Core capital of less than IDR 1 trillion (BUKU 1) code 1

- Core capital of IDR 1 trillion up to below IDR 5 trillion (BUKU 2) code 2

- Core capital IDR 5 trillion up to below IDR 30 trillion (BUKU 3 ) code 3

- Core capital more than IDR 30 trillion (BUKU 4) code 4

In this research, there are 13 classifications related to interaction of bank ownership types and bank core capital (BUKU), as shown in Table 1 below.

Table 1. Classifications related to interaction of bank ownership types and bank core capital (BUKU)

\begin{tabular}{ccc}
\hline Bank ownership types & Bank's Buku & Interaction code \\
\hline 1 & 1 & 1 \\
\hline 1 & 2 & 2 \\
\hline 1 & 3 & 3 \\
\hline 2 & 1 & 4 \\
\hline 2 & 2 & 5 \\
\hline 2 & 3 & 6 \\
\hline 3 & 2 & 7 \\
\hline 3 & 3 & 8 \\
\hline 3 & 4 & 9 \\
\hline 4 & 1 & 10 \\
\hline 4 & 2 & 11 \\
\hline 4 & 3 & 12 \\
\hline 4 & 4 & 13 \\
\hline & &
\end{tabular}

\section{RESULTS AND DISCUSSIONS}

The test results have gone through fulfilling the assumptions of the analytical tools used. Table 2 below presents descriptive statistics of bank ownership types and bank BUKU.

Table 2. Descriptive Statistics

\begin{tabular}{|c|c|c|c|c|}
\hline \multicolumn{5}{|c|}{ Dependent Variable: NPL } \\
\hline $\mathbf{N}$ & BUKU & Mean & Std. Deviation & $\mathbf{N}$ \\
\hline \multirow[t]{4}{*}{1} & 1 & .02705417 & .015516162 & 24 \\
\hline & 2 & .01499583 & .011771704 & 120 \\
\hline & 3 & .00807847 & .006321870 & 144 \\
\hline & Total & .01254201 & .011260081 & 288 \\
\hline \multirow[t]{4}{*}{2} & 1 & .01191833 & .018018930 & 120 \\
\hline & 2 & .02063661 & .061289668 & 336 \\
\hline & 3 & .01320938 & .009311115 & 96 \\
\hline & Total & .01744964 & .048835539 & 552 \\
\hline \multirow[t]{4}{*}{3} & 2 & .02773125 & .012858331 & 48 \\
\hline & 3 & .02718958 & .010075718 & 48 \\
\hline & 4 & .00818750 & .002547848 & 72 \\
\hline & Total & .01920060 & .013016004 & 168 \\
\hline \multirow[t]{5}{*}{4} & 1 & .06350577 & .332288905 & 312 \\
\hline & 2 & .01915112 & .039207683 & 624 \\
\hline & 3 & .01653250 & .011018954 & 240 \\
\hline & 4 & .02680313 & .144919066 & 96 \\
\hline & Total & .03011399 & .172429799 & 1272 \\
\hline
\end{tabular}




\begin{tabular}{|c|c|c|c|c|}
\hline \multirow[t]{5}{*}{ Total } & 1 & .04801162 & .275861464 & 456 \\
\hline & 2 & .01951667 & .044647503 & 1128 \\
\hline & 3 & .01459148 & .010895022 & 528 \\
\hline & 4 & .01882500 & 109704680 & 168 \\
\hline & Total & .02402412 & .131286368 & 2280 \\
\hline
\end{tabular}

In Table 3, the results of Two Way ANOVA are presented.

Table 3. Two Way ANOVA Tests of Between-Subjects Effects

\begin{tabular}{|c|c|c|c|c|c|}
\hline \multicolumn{6}{|c|}{ Dependent Variable: NPL } \\
\hline Source & $\begin{array}{c}\text { Type III Sum } \\
\text { of Squares }\end{array}$ & df & $\begin{array}{l}\text { Mean } \\
\text { Square }\end{array}$ & $\mathbf{F}$ & Sig. \\
\hline $\begin{array}{l}\text { 2279Corrected } \\
\text { Model }\end{array}$ & $.614^{\mathrm{a}}$ & 12 & .051 & 2.999 & .000 \\
\hline Intercept & .411 & 1 & .411 & 24.108 & .000 \\
\hline Type & .132 & 3 & .044 & 2.586 & .052 \\
\hline BUKU & .069 & 3 & .023 & 1.350 & .256 \\
\hline Type * BUKU & .203 & 6 & .034 & 1.983 & .065 \\
\hline Error & 38.667 & 2267 & .017 & & \\
\hline Total & 40.597 & 2280 & & & \\
\hline Corrected Total & 39.281 & 2279 & & & \\
\hline
\end{tabular}

From the results of the two way ANOVA test, it was found that at a significant level of 0.10 the main effect of bank ownership types had a significant effect on the performance of NPL management. From Table 3, it was found that the main effect of banks' BUKU had no significant effect on the performance of NPL management. This finding is in line with the findings of Sugiarto who found not enough evidence to conclude that bigger banks with higher core capital classification has better performance than smaller banks with lower core capital classification (Sugiarto. 2016).

In contrast to the findings of Damayanti, P., \& Savitri, D. A. M. (2018) who found that the bank size and capital adequacy ratio (CAR) has a positive effect on the bank profitability performance, the findings of this study after core capital were classified into banks BUKU did not find significant effect of banks BUKU on NPL performance. As an explanation, it can be argued that in the same class of banks BUKU there are variations in the amount of core capital and variations in the type of bank ownership that cause a mutual effect on the NPL performance.
The effect of mutual closure can be broken down through an analysis of the interaction effect of the amount of core capital and the type of bank ownership. Another argument that can be put forward is that banking industry inherently carries risks that cannot be eliminated as a whole. Banks operating in Indonesia are closely monitored by BI and OJK. The supervisory authority enforces a uniform level of rigorous supervision of all banks operating in Indonesia, especially on the performance of banks' NPL which play a major role in the stability of the banking industry.

The results in Table 3 also show that at a significant level of 0.10 the interaction effect of bank ownership type and banks' BUKU had a significant effect on the performance of NPL management.

Table 4. Descriptive statistics of NPL performance for 4 classifications of bank types

\begin{tabular}{lcccc}
\hline $\begin{array}{l}\text { Bank } \\
\text { ownership } \\
\text { types }\end{array}$ & $\mathbf{N}$ & Mean & $\begin{array}{c}\text { Std. } \\
\text { Deviation }\end{array}$ & Std. Error \\
\hline 1 & 288 & .01254201 & .011260081 & .000663507 \\
\hline 2 & 552 & .01744964 & .048835539 & .002078579 \\
\hline 3 & 168 & .01920060 & .013016004 & .001004206 \\
\hline 4 & 1272 & .03011399 & .172429799 & .004834691 \\
\hline Total & 2280 & .02402412 & .131286368 & .002749490 \\
\hline
\end{tabular}

For NPL performance, a lower NPL value indicates a better NPL management ability. From the descriptive statistics, it was found that the highest NPL management performance was foreign and mixed banks with a mean NPL of 0.01254201 . Besides showing the lowest mean NPL, the performance of NPL management of foreign and mixed banks was more stable than banks belonging to other types. The standard deviation of NPL of 0.011260081 is the smallest compared to the standard deviation of NPLs of banks belonging to other types.

The post hoc test results using the level of significance 0.1 with LSD test as shown in Table 5 show that the performance of NPL management of foreign and mixed banks is significantly different from private banks, but not significantly 
different from banks classified as BPD and BUMN. Further investigation of the post hoc test found that the performance of banks classified as BPD banks was also significantly different from private banks. In the conditions of the rigor of testing enhanced by Tukey HSD test, there was no significant difference in the NPL management ability of the four bank ownership types of banks studied.

Table 5. The summary of the post hoc test result

\begin{tabular}{cccc}
\hline & & TUKEY & LSD \\
\cline { 3 - 4 } (I) Type & (J) Type & $\begin{array}{c}\text { Mean } \\
\text { Difference (I-J) }\end{array}$ & $\begin{array}{c}\text { Mean } \\
\text { Difference (I-J) }\end{array}$ \\
\hline 1 & 4 & -.017571980 & $-.017571980^{*}$ \\
\hline 2 & 4 & -.012664356 & $-.012664356^{*}$ \\
\hline 4 & 1 & .017571980 & $.017571980^{*}$ \\
\hline 4 & 2 & .012664356 & $.012664356^{*}$ \\
\hline *. The mean difference is significant at the 0.10 level
\end{tabular}

Descriptive statistics of the interaction of bank ownership types and banks' BUKU are presented in Table 6 below.

Table 6. Descriptive statistics of the interaction of bank ownership types and banks' BUKU

\begin{tabular}{cccc}
\hline INTR & $\mathbf{N}$ & Mean & Std. Deviation \\
\hline 1 & 24 & .02705417 & .015516162 \\
\hline 2 & 120 & .01499583 & .011771704 \\
\hline 3 & 144 & .00807847 & .006321870 \\
\hline 4 & 120 & .01191833 & .018018930 \\
\hline 5 & 336 & .02063661 & .061289668 \\
\hline 6 & 96 & .01320938 & .009311115 \\
\hline 7 & 48 & .02773125 & .012858331 \\
\hline 8 & 48 & .02718958 & .010075718 \\
\hline 9 & 72 & .00818750 & .002547848 \\
\hline 10 & 312 & .06350577 & .332288905 \\
\hline 11 & 624 & .01915112 & .039207683 \\
\hline 12 & 240 & .01653250 & .011018954 \\
\hline 13 & 96 & .02680313 & .144919066 \\
\hline Total & 2280 & .02402412 & .131286368 \\
\hline & & &
\end{tabular}

Descriptive statistics of the interaction of bank ownership types and banks' BUKU that have been sorted on the basis of the mean NPL from the smallest to the largest values are shown in Table 7.

The results of the NPL management performance ranking for the interaction of bank ownership type and banks' BUKU show that the interaction with code 3 , namely foreign and mixed banks in the classification of BUKU 3 has the best rating. However, not all banks classified as foreign and mixed types have a significantly better NPL performance than the interaction of other bank types and banks' BUKU. The types of foreign and mixed banks in the buku classification 1 (code 1 ) and 2 (code 2) have no better performance even when compared to banks classified as BPD and BUMN types. The lowest NPL management performance is found in private-type banks classified in Buku 1.

More detailed search results using the post hoc test using both the Tukey test and the LSD test as can be seen in Table 8 strengthen the indications obtained from descriptive statistics. Although not all Tukey and LSD test results show the same results, there are many similarities in the results of the two tests which generally indicate that the interaction performance with Code 10, which in this case is a private bank in the classification of BUKU 1, is worse than other interactions with codes 2,3,4,5 and 6 for Tukey's test and worse than other interactions with codes $2,3,4,5,6$, $7,8,9,11,12$ and 13 for LSD test. The performance of banks which are included in the interaction with code 10 is only not significantly different from banks with code 1 , namely foreign and mixed banks which are classified in the classification of BUKU 1. Although the performance of foreign and mixed banks NPL management, those classified in the classification of BUKU 1 are better than interaction performance with code 10 but the difference in performance shown has not been able to show a significant difference at the level of confidence 0.1 . Thus, the status as a foreign and mixed bank does not guarantee that it will have a better NPL management capability compared to banks of other ownership types. On closer inspection, it seems that the role of core capital in the ability to manage bank NPLs is evident. However, an increase in core capital is indicated to increase the ability of banks to manage their NPLs. Foreign and mixed banks with higher core capital are better able to manage their NPL than those with lower core capital, even though the difference in NPL management 
capabilities between foreign and mixed banks in various classifications of core capital has not shown a significant difference at the level of confidence 0.1 .

Table 7. Descriptive statistics of the interaction of bank ownership types and banks' BUKU that have been sorted on the basis of the mean NPL

\begin{tabular}{cccc}
\hline INTR & $\mathbf{N}$ & Mean & Std. Deviation \\
\hline 3 & 144 & 0.008078 & 0.006322 \\
\hline 9 & 72 & 0.008188 & 0.002548 \\
\hline 4 & 120 & 0.011918 & 0.018019 \\
\hline 6 & 96 & 0.013209 & 0.009311 \\
\hline 2 & 120 & 0.014996 & 0.011772 \\
\hline 12 & 240 & 0.016533 & 0.011019 \\
\hline 11 & 624 & 0.019151 & 0.039208 \\
\hline 5 & 336 & 0.020637 & 0.06129 \\
\hline 13 & 96 & 0.026803 & 0.144919 \\
\hline 1 & 24 & 0.027054 & 0.015516 \\
\hline 8 & 48 & 0.02719 & 0.010076 \\
\hline 7 & 48 & 0.027731 & 0.012858 \\
\hline 10 & 312 & 0.063506 & 0.332289 \\
\hline
\end{tabular}

Table 8. The results of the post hoc test of the interaction of bank ownership types and banks' BUKU

\begin{tabular}{|c|c|c|c|}
\hline & & Tukey HSD & LSD \\
\hline (I) INTR & (J) INTR & $\begin{array}{c}\text { Mean } \\
\text { Difference (I-J) }\end{array}$ & $\begin{array}{c}\text { Mean } \\
\text { Difference (I-J) }\end{array}$ \\
\hline 2 & 10 & $-.048509936^{*}$ & $-.048509936^{*}$ \\
\hline 3 & 10 & $-.055427297 *$ & $-.055427297^{*}$ \\
\hline 4 & 10 & $-.051587436^{*}$ & $-.051587436^{*}$ \\
\hline 5 & 10 & $-.042869162 *$ & $-.042869162 *$ \\
\hline 6 & 10 & $-.050296394 *$ & $-.050296394^{*}$ \\
\hline 7 & 10 & -.035774519 & $-.035774519 *$ \\
\hline 8 & 10 & -.036316186 & $-.036316186^{*}$ \\
\hline 9 & 10 & $-.055318269 *$ & $-.055318269 *$ \\
\hline 10 & 2 & $.048509936^{*}$ & $.048509936^{*}$ \\
\hline 10 & 3 & $.055427297^{*}$ & $.055427297 *$ \\
\hline 10 & 4 & $.051587436^{*}$ & $.051587436^{*}$ \\
\hline 10 & 5 & $.042869162^{*}$ & $.042869162^{*}$ \\
\hline 10 & 6 & $.050296394^{*}$ & $.050296394^{*}$ \\
\hline 10 & 7 & .035774519 & $.035774519 *$ \\
\hline 10 & 8 & .036316186 & $.036316186^{*}$ \\
\hline 10 & 9 & $.055318269 *$ & $.055318269^{*}$ \\
\hline 10 & 11 & $.044354647^{*}$ & $.044354647^{*}$ \\
\hline 10 & 12 & $.046973269 *$ & $.046973269 *$ \\
\hline 10 & 13 & .036702644 & $.036702644^{*}$ \\
\hline 11 & 10 & $-.044354647^{*}$ & $-.044354647^{*}$ \\
\hline 12 & 10 & $-.046973269 *$ & $-.046973269^{*}$ \\
\hline
\end{tabular}

\begin{tabular}{llll}
\hline 13 & 10 & -.036702644 & $-.036702644^{*}$ \\
\hline
\end{tabular}

*. The mean difference is significant at the 0.1 level

Descriptive statistics of the interactions of bank ownership types and banks' BUKU which have been sorted on the basis of Std. Deviation of NPL from the smallest value to the largest value is shown in the Table 9.

Table 9. Descriptive statistics of the interactions of bank ownership types and banks' BUKU which have been sorted on the basis of Std. Deviation of NPL

\begin{tabular}{cccc}
\hline INTR & $\mathbf{N}$ & Mean & Std. Deviation \\
\hline 9 & 72 & 0.008188 & 0.002548 \\
\hline 3 & 144 & 0.008078 & 0.006322 \\
\hline 6 & 96 & 0.013209 & 0.009311 \\
\hline 8 & 48 & 0.02719 & 0.010076 \\
\hline 12 & 240 & 0.016533 & 0.011019 \\
\hline 2 & 120 & 0.014996 & 0.011772 \\
\hline 7 & 48 & 0.027731 & 0.012858 \\
\hline 1 & 24 & 0.027054 & 0.015516 \\
\hline 4 & 120 & 0.011918 & 0.018019 \\
\hline 11 & 624 & 0.019151 & 0.039208 \\
\hline 5 & 336 & 0.020637 & 0.06129 \\
\hline 13 & 96 & 0.026803 & 0.144919 \\
\hline 10 & 312 & 0.063506 & 0.332289 \\
\hline
\end{tabular}

From Table 9, It is known that banks classified as having large core capital for each type of bank, except for private banks have better NPL management stability than those with smaller core capital. The first rank that shows the best NPL management stability are banks classified as state-owned banks with core capital classified in BUKU 4. The next rank is banks classified as foreign and mixed with BUKU 3 which in this case is the highest BUKU for the category of foreign and mixed banks. The third rank is occupied by BPD banks with core capital classified in BUKU 3 which in this case is the highest book for the BPD bank category. An unexpected condition was found in banks classified as private bank with BUKU 4 in fact having an unsatisfactory performance in NPL management stability because they were only better than private banks with BUKU 1 which showing the worst risk management performance stability. 


\section{CONCLUSION}

1. The main effect of bank ownership types had a significant effect on the performance of NPL management. Besides showing the lowest mean NPL, the performance of NPL management of foreign and mixed banks was more stable than banks belonging to other types.

2. The main effect of banks' BUKU had no significant effect on the performance of NPL management.

3. The interaction effect of bank ownership type and banks' BUKU had a significant effect on the performance of NPL management. The results of the NPL management performance ranking for the interaction of bank ownership type and banks' BUKU show that foreign and mixed banks in the classification of BUKU 3 has the best rating. Banks classified as having large core capital for each type of bank, except for private banks have better NPL management stability than those with smaller core capital. The status as a foreign and mixed bank does not guarantee that it will have a better NPL management capability compared to banks of other types. On closer inspection, it seems that the role of core capital in the ability to manage bank NPLs is evident.

\section{REFEREN CES}

Anbar, A., \& Alper, D. (2011). Bank specific and macroeconomic determinants of commercial bank profitability: Empirical evidence from Turkey. Business and economics research journal, 2(2), 139152.

Boby. (2019). Jenis-Jenis Bank: Apa Itu Bank BUKU 1,2,3, dan 4?. Retrieved October 14, 2019, from https:/ /www.moneysmart.id/jenis-jenis-bank-apa-itu-bank-buku-1-2-3-dan-4/

Claessens, S., Demirgüc, -Kunt, A., \& Huiinga, H. (2001). How does foreign entry affect the domestic banking markets? Journal of Banking and Finance, 25, 891-911.

Crystal, J.S., Dages G., Goldberg, L.S., (2001). Does foreign ownership contribute to sounder banks in emerging markets? The Latin American experience. Federal Reserve Bank of New York, Staff Reports, vol.137.

Damayanti, P., \& Savitri, D. A. M. (2018). Analisis pengaruh ukuran (size), capital adequacy ratio (car), pertumbuhan deposit, loan to deposit rasio (ldr), terhadap profitabilitas perbankan go public di Indonesia tahun 2005-2009. Jurnal Ilmu Manajemen Dan Akuntansi Terapan (JIMAT), 3(2), 45-54. ISSN 2656-4440. Retrieved from http://jurnal.stietotalwin.ac.id/index.php/jimat/article/view/ $42>$.

Diamond D. (1984) "Financial Intermediation and Delegated Monitoring", Review of Economic Studies 51, pp. 393-414

Diamond, D., \& Rajan, R. (2001). Liquidity Risk, Liquidity Creation, and Financial Fragility: A Theory of Banking. Journal of Political Economy,109(2), 287-327. doi:10.1086/319552

Fama E.F. (1980) "Fama Banking in the theory of finance”, Journal of Monetary Economics, 6 (1), pp. 39-57.

Global Association of Risk Professionals. (2005). Indonesia Certificate in Banking Risk and Regulation, Workbook Level 1. Global Association of Risk Professionals-Badan Sertifikasi Manajemen Risiko

Global Association of Risk Professionals. (2006). Indonesia Certificate in Banking Risk and Regulation, Workbook Level 2. Global Association of Risk Professionals-Badan Sertifikasi Manajemen Risiko

Gurley, Kennedy, C., , J., Shaw, E. and Enthoven, A., 1960. Money In A Theory Of Finance . The Economic Journal, Volume 70, Issue 279, 1 September 1960, Pages 568-569. Washington, D.C.: The Brookings Institution 
Hutagalung, E.N. Djumahir. \& Ratnawati, K. (2013). Analisa Rasio Keuangan terhadap Kinerja Bank Umum di Indonesia. Jurnal Aplikasi Manajemen, 11(1), 122-130

Jonathan Batten \& Xuan Vinh Vo. (2019). Determinants of Bank Profitability-Evidence from Vietnam Retrieved from https://www.tandfonline.com/doi/abs/10.1080/1540496X.2018.1524326

Kohlscheen, Et.al. (2018). Determinants of Bank Profitability in Emerging Markets. Retrieved from https://ssrn.com/abstract=3098196

Lardy, N. R. (2001). Foreign financial firms in Asia. In R. E. Litian, P. Masson, \& M. Pomerleano (Eds.), Open doors: Foreign participation in financial systems in developing countries (pp. 267-271). Washington DC: Brookings Institution Press.

Leland H., \& D. Pyle (1977). Informational Asymmetries, Financial Structure and Financial Intermediation, Journal of Finance, Vol. 32, pp. 371 - 387

Manlagnit, Maria Chelo V. (2011). The economic effect of foreign bank presence: evidence from the Philippines Journal of International Money and Finance, 201180 - 1194.

Otoritas Jasa Keuangan. (2019a). Kegiatan Usaha Bank Umum. Retrieved from https://www.ojk.go.id/id/ kanal/perbankan/Pages/Bank-Umum.aspx

Otoritas Jasa Keuangan. (2019b). Perbankan Syariah dan Kelembagaannya. Retrieved from https:// www.ojk.go.id/id/kanal/syariah/tentang-syariah/Pages/PBS-dan-Kelembagaan.aspx

Otoritas Jasa Keuangan. (2019c). Statistik Perbankan Indonesia Juli 2019. Retrieved from https:// www.ojk.go.id/id/kanal/perbankan/data-dan-statistik/statistik-perbankan-indonesia/ Default.aspx

Otoritas Jasa Keuangan. (2019d). Statistik Perbankan Syariah Juli 2019 . Retrieved from https:// www.ojk.go.id/id/kanal/syariah/data-dan-statistik/statistik-perbankan-syariah/Default.aspx

Otoritas Jasa Keuangan. (2019e). Siaran Pers Survei OJK 2019 Indeks Literasi Dan Inklusi Keuangan Meningkat. Retrieved From https://www.ojk.go.id/id/berita-dan-kegiatan/siaran-pers/Pages/ Siaran-Pers-Survei-OJK-2019-Indeks-Literasi-Dan-Inklusi-Keuangan-Meningkat.aspx

PBI No. 5/8/PBI/2003, 19 Mei 2003 sebagaimana diubah dengan PBI No. 11/25/PBI/2009, 1 Juli 2009; perihal Penerapan Manajemen Risiko bagi Bank Umum.

PBI No.13/1/PBI/2011 tanggal 5 Januari 2012 perihal Penilaian Tingkat Kesehatan Bank Umum.

PBI No. 14/18/PBI/2012 tentang Kewajiban Penyediaan Modal Minimum Bank Umum

PBI No. 14/26/PBI/2012 Tentang Kegiatan Usaha dan Jaringan Kantor Berdasarkan Modal IntiBank, dan diperbaharui dalam Peraturan Otoritas Jasa Keuangan Nomor 6/POJK.03/2016 tentang Kegiatan Usaha dan Jaringan Kantor Berdasarkan Modal Inti Bank.

POJK No. 6/POJK.03/2016 Tentang Kegiatan Usaha dan Jaringan Kantor Berdasarkan Modal Inti Bank Prasetyo, W. (2015). Analisis Faktor-Faktor Yang Mempengaruhi Profitabilitas Perbankan. Jurnal Ekonomi \& Studi Pembangunan, 7(1), 46-54

SE BI No.13/23/DPNP/2011 tgl 25 Oktober 2011 perihal Penerapan Manajemen Risiko bagi Bank Umum. SE BI No. 13/24/DPNP / 2011 tgl 25 Oktober 2011 perihal Penilaian Tingkat Kesehatan Bank Umum SE BI No. 14/37/DPNP/2012 tgl 27 Desember 2012 tentang KPMM sesuai Profil Risiko.

Sugiarto. (2016). Performance Evaluation of Indonesian Banks and Foreign Banks Operating in Indonesia Related to Classification of Capital. Advances in Economics, Business and Management Research, Volume 15. 1st Global Conference on Business, Management and Entrepreneurship (GCBME-16)

Sugiarto. (2017a). Formulasi Model Peer Group Bank. Workshop Model Peer Group Bank, Bank Jasa Jakarta. Jakarta, Juni 2017.

Sugiarto. (2017b). Core Capital Performance Evaluation of Banks Operating in Indonesia. International J ournal of Applied Business and Economic Research, ISSN: 0972-7302, Vol.15. Number 6. 2017.

Sugiarto. (2018). Time Series Analysis of Performance Consistency of Bank Peer Group Model. The $2^{\text {nd }}$ International Conference on E-Business and Internet (ICEBI 2018), 16-18 Mei 2018, National Taipei University of Business, Taiwan 
Sugiarto \& Karnadi Suryadi. (2018). Peer Group Model as a Reference of Banks Performance Assessment. The $3^{\text {rd }}$ Global Conference on Business, Management, and Entrepreneurship, Grand Mercure Hotel August $8^{\text {th }}$ 2018, Bandung

Sugiarto, Nursiana Adinoto, Budhijono Fongnawati. (2018). Model Peer Group Sebagai Patok Duga Penilaian Kinerja Bank. Laporan Akhir Penelitian Berbasis Kompetensi. STIE Wiyatamandala

Susanto, Anindya Pradipta \& Rokhim Rofikoh (2011). The Increase of Foreign Ownership and its Impact to the Performance, Competition \& Risk in Indonesian Banking Industry. Retrieved from SSRN: https://ssrn.com/abstract=1915234 or http://dx.doi.org/10.2139/ssrn.1915234

Undang-undang Republik Indonesia Nomor 10 Tahun 1998. Tentang Perubahan Atas Undang-undang nomor 7 Tahun 1992 Tentang Perbankan.

Unite, Angelo A. \& Sullivan, Michael J. (2003). The effect of foreign entry and ownership structure on the Philippine domestic banking market. Journal of Banking \& Finance, 27 (2003) 2323-2345. www.elsevier.com/locate/econbase

Yüksel, S.; Mukhtarov, S.; Mammadov, E.; Özsarı, M. (2018). Determinants of Profitability in the Banking Sector: An Analysis of Post-Soviet Countries. Retrieved from https://www.mdpi.com/2227$7099 / 6 / 3 / 41$ 